Review

\title{
Current Utility of Plant Growth-Promoting Rhizobacteria as Biological Control Agents towards Plant-Parasitic Nematodes
}

\author{
Pratima Subedi ${ }^{\dagger}$, Kaitlin Gattoni ${ }^{\dagger}$, Wenshan Liu, Kathy S. Lawrence * and Sang-Wook Park * \\ Department of Entomology and Plant Pathology, Auburn University, Auburn, AL 36849, USA; \\ pzs0066@auburn.edu (P.S.); Kmg0073@tigermail.auburn.edu (K.G.); wzl0028@auburn.edu (W.L.) \\ * Correspondence: lawrekk@auburn.edu (K.S.L.); swpark@auburn.edu (S.-W.P.) \\ † P.S. and K.G. contributed equally to this work.
}

Received: 27 July 2020; Accepted: 2 September 2020; Published: 9 September 2020

\begin{abstract}
Plant-parasitic nematodes (PPN) are among the most economically and ecologically damaging pests, causing severe losses of crop production worldwide. Chemical-based nematicides have been widely used, but these may have adverse effects on human health and the environment. Hence, biological control agents (BCAs) have become an alternative option for controlling PPN, since they are environmentally friendly and cost effective. Lately, a major effort has been made to evaluate the potential of a commercial grade strain of plant growth-promoting rhizobacteria (PGPR) as BCAs, because emerging evidence has shown that PGPR can reduce PPN in infested plants through direct and/or indirect antagonistic mechanisms. Direct antagonism occurs by predation, release of antinematicidal metabolites and semiochemicals, competition for nutrients, and niche exclusion. However, the results of direct antagonism may be inconsistent due to unknown endogenous and exogenous factors that may prevent PGPR from colonizing plant's roots. On the other hand, indirect antagonism may occur from the induced systemic resistance (ISR) that primes whole plants to better fight against various biotic and abiotic constraints, actuating faster and/or stronger defense responses (adaption), enhancing their promise as BCAs. Hence, this review will briefly revisit (i) two modes of PGPR in managing PPN, and (ii) the current working models and many benefits of ISR, in the aim of reassessing current progresses and future directions for isolating more effective BCAs and/or developing better PPN management strategy.
\end{abstract}

Keywords: direct/indirect antagonism; induced systemic resistance (ISR); jasmonic acid; management; salicylic acid; systemic acquired resistance (SAR)

\section{Introduction}

Plant-parasitic nematodes (PPN) are biotrophic parasites that cause billions of dollars in economic damages on major food crops including corn (Zea mays L.), potato (Solanum tuberosum L.), soybean (Glycine max (L.) Merr.), as well as an important fiber crop, cotton (Gossypium hirsutum L.) [1]. Thus, a variety of management strategies using chemical nematicides, cultural control, resistant varieties and biological control (BCA) have long been tested, and employed to manage PPN. Nematicides, however, may not always be environmentally friendly, having hazardous and non-target impacts on flora and fauna including many natural enemies [2]. Although nematicides may initially reduce PPN populations and provide protection from their damage, these plants may allow the increase of populations at the end of the growing season. The following year will require an additional application of costly nematicides [3]. On the other hand, cultural control and resistant cultivars are not always available $[4,5]$. Hence, increasing attention has lately been drawn to the potential use of BCAs as an effective, inexpensive, and environmentally friendly tools of PPN management [3]. 
BCAs, a natural enemy or predator, can work by direct or indirect antagonism. Direct antagonism occurs in general through a predation, a release of toxic metabolites or a competition for nutrients and niche exclusion, whereas indirect antagonism can operate via induced systemic resistance (ISR) or systemic acquired resistance (SAR) [3]. ISR is defined as an enhanced plant resistance induced by plant growth-promoting rhizobacteria (PGPR) and typically employs jasmonic acid (JA) and ethylene (ET) hormone signaling [6]. SAR is also a form of induced plant resistance activated by an exposure to necrotizing biotrophs, which requires the accumulation of salicylic acid (SA) in infected and systemic tissues [7]. Over the last several decades, increasing efforts have been invested to examine the efficacy and practicality of PGPR in the hope of commercializing them as economic BCAs (Tables 1-4). PGPR are well proven "effective biostimulants", facilitating plant growth and productivity, and being concurrently able to improve plant resistance against a broad range of microbial pathogens and insect herbivores. Moreover, PGPR can prime plants to better adapt or acclimate towards various abiotic stresses including drought, salinity, and extreme temperatures [8]. Therefore, the successful development of commercial PGPR (BCAs) will greatly aid in upgrading plants' own survival capacity against PPN as well as many other ecological constraints, without "trading off" yield potential. However, the current utility of PGPR in the field is still limited, largely due to our little knowledge of, in the molecular, biochemical and cellular levels, their mode of interactions with PPN and plants. Hence, this review will briefly revisit current working models of the mode of actions of PGPR with a focus of PPN management, and pinpoint information gaps within, which help revamp unique and alternative prospective for the future studies.

Table 1. A list of plant growth-promoting rhizobacteria (PGPR) conferring direct antagonisms against plant-parasitic nematodes (PPN).

\begin{tabular}{|c|c|c|c|}
\hline PGPR & Target PPN & Molecules or Modes & References \\
\hline Bacillus cereus & $\begin{array}{l}\text { Heterodera avenae, } \\
\text { Meloidogyne incognita, } \\
\text { Meloidogyne javanica }\end{array}$ & $\begin{array}{l}\text { Sphingosine, Protease, } \\
\text { Chitinase, Antibiotic } \\
\text { production, Secondary } \\
\text { metabolites }\end{array}$ & $\begin{array}{l}\text { Oka et al., } 2008 \text { [9]; Gao et al., } \\
2016 \text { [10]; Ahmed, } 2019 \text { [11] }\end{array}$ \\
\hline Bacillus coagulans & Meloidogyne incognita & Hydrolytic enzymes & $\begin{array}{l}\text { Ambo et al., } 2010 \text { [12]; } \\
\text { Serfoji et al., } 2013 \text { [13]; } \\
\text { Xiang et al., } 2018 \text { [4] }\end{array}$ \\
\hline Bacillus firmus & $\begin{array}{l}\text { Ditylenchus dipasi, } \\
\text { Heterodera spp., } \\
\text { Meloidogyne incognita, } \\
\text { Pratylenchus spp., } \\
\text { Radopholus similis }\end{array}$ & $\begin{array}{l}\text { Sep } 1 \text { protease, } \\
\text { Secondary metabolites }\end{array}$ & $\begin{array}{l}\text { Giannakou et al., 2004 [14]; } \\
\text { Mendoza et al., } 2008 \text { [15]; } \\
\text { Terefe et al., 2009 [16]; } \\
\text { Terefe et al., } 2012 \text { [17]; } \\
\text { Xiong et al., } 2015 \text { [18]; } \\
\text { Geng et al., 2016 [19]; Bayer } \\
\text { Crop Science [20] }\end{array}$ \\
\hline $\begin{array}{l}\text { Bacillus } \\
\text { licheniformis }\end{array}$ & $\begin{array}{l}\text { Bursaphelenchulus xylophi } \\
\text { lus, Meloidogyne incognita }\end{array}$ & Protease, Chitinase & $\begin{array}{l}\text { Siddiqui and Husain } \\
1991 \text { [21]; Siddiqui and } \\
\text { Mahmood } 1992 \text { [22]; } \\
\text { Jeong et al., } 2015 \text { [23]; } \\
\text { El-Nagdi et al., } 2019 \text { [24] }\end{array}$ \\
\hline $\begin{array}{l}\text { Bacillus } \\
\text { megaterium }\end{array}$ & $\begin{array}{l}\text { Heterodera glycines, } \\
\text { Meloidogyne incognita, } \\
\text { Meloidogyne graminicola }\end{array}$ & $\begin{array}{l}\text { Protease, Secondary } \\
\text { metabolites }\end{array}$ & $\begin{array}{l}\text { Kloepper et al., } 1992 \text { [25]; } \\
\text { Padgham et al., } 2007 \text { [26]; } \\
\text { Mostafa et al., } 2018 \text { [27] }\end{array}$ \\
\hline $\begin{array}{l}\text { Bacillus pumilus } \\
\text { L1 }\end{array}$ & $\begin{array}{l}\text { Heterodera glycines, } \\
\text { Meloidogyne arenaria }\end{array}$ & Protease, Chitinase & $\begin{array}{l}\text { Lee and Kim } 2015 \text { [28]; } \\
\text { Forghani and } \\
\text { Hajihassani et al., } 2020 \text { [29] }\end{array}$ \\
\hline
\end{tabular}


Table 1. Cont.

\begin{tabular}{|c|c|c|c|}
\hline PGPR & Target PPN & Molecules or Modes & References \\
\hline Bacillus subtilis & $\begin{array}{l}\text { Helicotylenchus } \\
\text { multicinctus, } \\
\text { Meloidogyne graminicola, } \\
\text { Meloidogyne incognita, } \\
\text { Meloidogyne javanica, } \\
\text { Rotylenchulus reniformis }\end{array}$ & $\begin{array}{l}\text { Lipopeptide antibiotics, } \\
\text { Hydrolytic enzymes, } \\
\text { Secondary metabolites }\end{array}$ & $\begin{array}{l}\text { Prakob et al., } 2009 \text { [30]; } \\
\text { Kavitha et al., } 2012 \text { [31]; } \\
\text { Basyony and Abo-Zaid, } \\
2018 \text { [32]; Mazzuchelli et al., } \\
2020 \text { [33]; Gautam et al., } \\
1995 \text { [34] }\end{array}$ \\
\hline $\begin{array}{l}\text { Bacillus } \\
\text { thuringiensis }\end{array}$ & $\begin{array}{l}\text { Heterodera glycines, } \\
\text { Meloidogyne incognita }\end{array}$ & $\begin{array}{l}\text { Bt crystal protein (toxin } \\
\text { protein), Thuringiensin } \\
\text { ( } \beta \text {-exotoxin) }\end{array}$ & $\begin{array}{l}\text { Noel, } 1990 \text { [35]; Wei et al., } \\
2003 \text { [36]; Mohammed et al., } \\
2008 \text { [37] }\end{array}$ \\
\hline $\begin{array}{l}\text { Corynebacterium } \\
\text { paurometabolum }\end{array}$ & Meloidogyne incognita & $\begin{array}{l}\text { Hydrogen sulfide, } \\
\text { Chitinase }\end{array}$ & $\begin{array}{l}\text { Mena and Pimentel, } \\
2002 \text { [38] }\end{array}$ \\
\hline $\begin{array}{l}\text { Pasteuria } \\
\text { penetrans }^{1}\end{array}$ & Meloidogyne spp. & Predation & $\begin{array}{l}\text { Mankau et al., } 1976 \text { [39]; } \\
\text { Mankau and Prasad, } \\
1977 \text { [40]; Dube and } \\
\text { Smart, [41]; Sayre and Starr } \\
1975 \text { [42]; Bhuiyan et al., } \\
2018 \text { [43] }\end{array}$ \\
\hline Pasteuria thornei ${ }^{1}$ & Pratylenchus spp. & Predation & $\begin{array}{l}\text { Mankau et al., } 1976 \text { [41]; } \\
\text { Atibalentja et al., } 2000 \text { [44] }\end{array}$ \\
\hline $\begin{array}{l}\text { Pasteuria } \\
\text { nishizawae }^{1}\end{array}$ & $\begin{array}{l}\text { Globodera spp., } \\
\text { Heterodera spp. }\end{array}$ & Predation & Sayre and Wergin, 1991 [45] \\
\hline $\begin{array}{l}\text { Pseudomonas } \\
\text { aeruginosa }\end{array}$ & $\begin{array}{l}\text { Caenorhabditis elegans, } \\
\text { Meloidogyne incognita, } \\
\text { Meloidogyne javanica }\end{array}$ & $\begin{array}{l}\text { Hydrogen cyanide } \\
(\mathrm{HCN})\end{array}$ & $\begin{array}{l}\text { Siddiqui and } \\
\text { Ehteshamul-Haque, } \\
2001 \text { [46]; Gallagher and } \\
\text { Manoil, 2001 [47]; Singh and } \\
\text { Siddiqui, } 2010 \text { [48] }\end{array}$ \\
\hline $\begin{array}{l}\text { Pseudomonas. } \\
\text { fluorescens F113 }\end{array}$ & Globodera rostochinensis & $\begin{array}{l}\text { 2,4-diacetylphloroglucinol } \\
\text { (DAPG) }\end{array}$ & Cronin et al., 1997 [49] \\
\hline $\begin{array}{l}\text { Pseudomonas } \\
\text { fluorescens CHA0 }\end{array}$ & $\begin{array}{l}\text { Meloidogyne incognita, } \\
\text { Meloidogyne javanica }\end{array}$ & $\begin{array}{l}\text { HCN, DAPG, } \\
\text { Pyoluteorin, } \\
\text { Extracellular protease }\end{array}$ & $\begin{array}{l}\text { Siddiqui and Shaukat, } \\
2003 \text { [50]; Hamid et al., } \\
2003 \text { [51]; Siddiqui et al., } \\
2005 \text { [52] }\end{array}$ \\
\hline $\begin{array}{l}\text { Pseudomonas } \\
\text { fluorescens } \\
\text { Wood } 1 \mathrm{R}\end{array}$ & Meloidogyne incognita & DAPG & Timper et al., 2009 [53] \\
\hline $\begin{array}{l}\text { Pseudomonas } \\
\text { stutzeri }\end{array}$ & Meloidogyne incognita & $\mathrm{HCN}$ & Khan et al., 2016 [54] \\
\hline $\begin{array}{l}\text { Serratia } \\
\text { marcescens }\end{array}$ & $\begin{array}{l}\text { Meloidogyne incognita, } \\
\text { Meloidogyne javanica, } \\
\text { Radopholus similis }\end{array}$ & $\begin{array}{l}\text { Volatile metabolites, } \\
\text { Prodigiosin }\end{array}$ & $\begin{array}{l}\text { Zabaketa-Mejia, } 1985 \text { [55]; } \\
\text { Rahul et al., } 2014 \text { [56] }\end{array}$ \\
\hline
\end{tabular}


Table 2. A list of PGPR conferring indirect antagonisms against PPN.

\begin{tabular}{|c|c|c|c|}
\hline PGPR & Target PPN & Modes & References \\
\hline $\begin{array}{l}\text { Agrobacterium } \\
\text { radiobacter }(\mathrm{G} 12)\end{array}$ & Globodera spp. & ISR & $\begin{array}{l}\text { Hasky-Guenther et al., } 1998 \text { [57]; } \\
\text { Hackenberg and Sikora, } 1992 \text { [58]; } \\
\text { Racke and Sikora, } 1992 \text { [59]; } \\
\text { Hackenberg et al., } 1999 \text { [60] }\end{array}$ \\
\hline $\begin{array}{l}\text { Bacillus } \\
\text { amyloliquefaciens } \\
\text { (syn. Bacillus } \\
\text { velezensis) }\end{array}$ & $\begin{array}{l}\text { Heterodera glycine, } \\
\text { Meloidogyne incognita }\end{array}$ & ISR and SAR & $\begin{array}{l}\text { Ryu et al., } 2004 \text { [61]; Beris et al., } \\
2018 \text { [62]; Burkett- Cadena et al., } \\
2008 \text { [63]; Choudhary et al., } \\
2009 \text { [64]; Li et al., } 2015 \text { [65]; } \\
\text { Xiang et al., } 2016 \text { [66]; Xie et al., } \\
2018 \text { [67] }\end{array}$ \\
\hline Bacillus cereus & $\begin{array}{l}\text { Meloidogyne javanica, } \\
\text { Meloidogyne incognita }\end{array}$ & ISR & $\begin{array}{l}\text { Xiang et al., } 2016 \text { [66]; } \\
\text { Halfeld-Vieira et al., } 2006 \text { [68]; } \\
\text { Niu et al., } 2011 \text { [69]; Jiang et al., } \\
2020 \text { [70] }\end{array}$ \\
\hline Bacillus mojavensis & Meloidogyne incognita & ISR & $\begin{array}{l}\text { Xiang et al., } 2016 \text { [66]; Liu et al., } \\
2016 \text { [71] }\end{array}$ \\
\hline Bacillus mycoides & Meloidogyne incognita & ISR and SAR & $\begin{array}{l}\text { Xiang et al., } 2016 \text { [66]; } \\
\text { Barbagus et al., } 2004 \text { [72] }\end{array}$ \\
\hline Bacillus pasteurii & Meloidogyne incognita & ISR & $\begin{array}{l}\text { Xiang et al., } 2016 \text { [66]; Ryu et al., } \\
2003 \text { [73] }\end{array}$ \\
\hline Bacillus pumilus & $\begin{array}{l}\text { Heterodera glycine, } \\
\text { Meloidogyne incognita }\end{array}$ & ISR and SAR & $\begin{array}{l}\text { Xiang et al., } 2016 \text { [66]; Zhang et al., } \\
2002 \text { [74]; Barbagus et al., } 2004 \text { [75]; } \\
\text { Kavitha et al., } 2007 \text { [76]; } \\
\text { Choudhary et al., } 2007 \text { [77]; } \\
\text { Lastochkina et al., } 2017 \text { [78] }\end{array}$ \\
\hline Bacillus sphaericus & $\begin{array}{l}\text { Globodera pallida, } \\
\text { Meloidogyne incognita }\end{array}$ & ISR & $\begin{array}{l}\text { Hasky-Guenther et al., } 1998 \text { [57]; } \\
\text { Racke and Sikora 1992 [59]; } \\
\text { Xiang et al., } 2016 \text { [66] }\end{array}$ \\
\hline Bacillus subtilis & $\begin{array}{l}\text { Heterodera cajani, } \\
\text { Meloidogyne arenaria, } \\
\text { Meloidogyne incognita, } \\
\text { Meloidogyne javanica }\end{array}$ & ISR and SAR & $\begin{array}{l}\text { Ryu et al., } 2004 \text { [61]; Xiang et al., } \\
2016 \text { [66]; Kavitha et al., 2007 [76]; } \\
\text { Choudhary et al., } 2007 \text { [77]; } \\
\text { Lastochkina et al., } 2017 \text { [78] }\end{array}$ \\
\hline $\begin{array}{l}\text { Bacillus } \\
\text { thuringiensis }\end{array}$ & $\begin{array}{l}\text { Aphelenchus avenae, } \\
\text { Meloidogyne incognita }\end{array}$ & ISR & $\begin{array}{l}\text { Zhang et al., } 2002 \text { [74] Akram et al., } \\
2013 \text { [79]; Zuckerman et al.; } \\
1993 \text { [80] }\end{array}$ \\
\hline $\begin{array}{l}\text { Pseudomonas } \\
\text { aeruginosa }\end{array}$ & Meloidogyne javanica & ISR and SAR & $\begin{array}{l}\text { Audenaert et al.,2013 [81]; } \\
\text { Fatima et al., } 2017 \text { [82] }\end{array}$ \\
\hline $\begin{array}{l}\text { Pseudomonas } \\
\text { fluorescens }\end{array}$ & $\begin{array}{l}\text { Meloidogyne incognita, } \\
\text { Meloidogyne javanica }\end{array}$ & ISR and SAR & $\begin{array}{l}\text { Siddiqui and Shaukat } 2003 \text { [50]; } \\
\text { Choudhary et al., } 2007 \text { [77]; } \\
\text { Krechel et al., } 2002 \text { [83]; Saikia et al., } \\
2013 \text { [84]; de Vleesschauwer et al., } \\
2012 \text { [85]; Leeman et al., } 1995 \text { [86] }\end{array}$ \\
\hline $\begin{array}{l}\text { Pseudomonas } \\
\text { putida }\end{array}$ & Meloidogyne incognita & ISR & $\begin{array}{l}\text { Krechel et al., } 2002 \text { [83]; } \\
\text { Almaghrabi et al., } 2013 \text { [87] }\end{array}$ \\
\hline Rhizobium etli & Meloidogyne spp. & ISR & Reitz et al., 2000 [88] \\
\hline $\begin{array}{l}\text { Serratia } \\
\text { marcescens }\end{array}$ & Meloidogyne incognita & ISR & $\begin{array}{l}\text { Zhang et al., } 2002 \text { [74]; } \\
\text { Almaghrabi et al., } 2013 \text { [87] }\end{array}$ \\
\hline $\begin{array}{l}\text { Trichoderma } \\
\text { harzianum }^{1}\end{array}$ & Meloidogyne incognita & ISR and SAR & Martínez-Medina et al., 2017 [89] \\
\hline
\end{tabular}


Table 3. A list of PGPR commercialized as BCAs against PPN.

\begin{tabular}{|c|c|c|c|}
\hline $\begin{array}{l}\text { Commercial } \\
\text { Products }\end{array}$ & PGPR & Applications & References \\
\hline BioNemaGon $^{\mathrm{TM}}$ & Bacillus firmus & $\begin{array}{l}\text { Reduce nematode population and root } \\
\text { infestation by nematodes in vegetables } \\
\text { and herbs }\end{array}$ & [90] \\
\hline BioYield $^{\mathrm{TM}}$ & $\begin{array}{l}\text { Bacillus subtilis GB03, } \\
\text { Bacillus amyloliquefaciens }\end{array}$ & $\begin{array}{l}\text { Nematodes in tomato, strawberry, and } \\
\text { bell pepper }\end{array}$ & [65] \\
\hline Clariva ${ }^{\circledR}$ pn & Pasteuria nishizawae Pn1 & $\begin{array}{l}\text { Seed treatment; Target Heterodera glycines } \\
\text { to reduce feeding and reproduction, and } \\
\text { increase yields under heavy PPN } \\
\text { pressure. }\end{array}$ & [91] \\
\hline Deny, Blue Circle & Burlkholderia cepacia & $\begin{array}{l}\text { Inhibit egg hatching and mobility of } \\
\text { nematode juveniles }\end{array}$ & [92] \\
\hline $\begin{array}{l}\text { MeloCon }{ }^{\circledR} \text {, BioAct } \\
\text { and NemOut }\end{array}$ & $\begin{array}{l}\text { Purpureocillium lilacinus } \\
251\end{array}$ & $\begin{array}{l}\text { Inhibit root knot, burring, cyst, reniform, } \\
\text { spiral, sting, and root lesion nematodes. }\end{array}$ & [93] \\
\hline Naviva ST & Pasteuria sp. Ph3 & $\begin{array}{l}\text { Seed treatment; Inhibit Rotylenchulus } \\
\text { reniformis in cotton, soy, vegetables, } \\
\text { cucurbits, and floriculture. }\end{array}$ & [94] \\
\hline NewPro & $\begin{array}{l}\text { Pasteuria usgae } \mathrm{Bl} 1+ \\
\text { Pasteuria sp. Ph3 }\end{array}$ & $\begin{array}{l}\text { Inhibit lance and sting nematodes in turf } \\
\text { (Bermudagrass and St. Augustine grass) }\end{array}$ & [95] \\
\hline Nortica $10 \mathrm{WP}$ & Bacillus firmus I-1582 & $\begin{array}{l}\text { Inhibit cyst, lance, lesion, ring, root knot } \\
\text { sheath, spiral, sting, and stunt nematodes } \\
\text { in turf. }\end{array}$ & [96] \\
\hline VOTiVO FS & Bacillus firmus I-1582 & $\begin{array}{l}\text { Seed treatment; inhibit a broad range of } \\
\text { nematodes. Available also as premix with } \\
\text { insecticide }\end{array}$ & [97] \\
\hline
\end{tabular}

Table 4. A list of PPN inhibitory PGPR with uncharacterized function.

\begin{tabular}{|c|c|c|c|}
\hline PGPR & Target PPN & Target Crops & References \\
\hline Alcaligenes faecalis & Meloidogyne incognita & Chickpea & Siddiqui and Mahmood, 1992 [22] \\
\hline $\begin{array}{l}\text { Azotobacter } \\
\text { chroococcum }\end{array}$ & $\begin{array}{l}\text { Meloidogyne incognita, } \\
\text { Meloidogyne javanica }\end{array}$ & Eggplant, Tomato & Bansal et al., 2002 [98] \\
\hline $\begin{array}{l}\text { Bacillus altitudinis, } \\
\text { Bacillus aerophilus, } \\
\text { Bacillus aryabhattai, } \\
\text { Bacillus galliciensis, } \\
\text { Bacillus } \\
\text { psychrosaccharolyticus, } \\
\text { Bacillus safensis, } \\
\text { Bacillus siamensis, } \\
\text { Bacillus simplex, } \\
\text { Bacillus toyonensis, } \\
\text { Bacillus } \\
\text { weihenstephanensis }\end{array}$ & Meloidogyne incognita & Cotton & Xiang et al., 2016 [66] \\
\hline Bacillus firmus & $\begin{array}{l}\text { Belonolaimus } \\
\text { longicaudatus }\end{array}$ & Bermudagrass & Crow, 2014 [99] \\
\hline Bacillus flexus & Meloidogyne incognita & Basil & Tiwari et al., 2017 [100] \\
\hline Bacillus isolates & $\begin{array}{l}\text { Heterodera cajani, } \\
\text { Meloidogyne incognita }\end{array}$ & Pigeon pea & Siddiqui and Shakeel, 2007 [101] \\
\hline $\begin{array}{l}\text { Bacillus } \\
\text { methylotrophicus }\end{array}$ & Meloidogyne incognita & Tomato & Zhou et al., 2016 [102] \\
\hline
\end{tabular}


Table 4. Cont.

\begin{tabular}{|c|c|c|c|}
\hline PGPR & Target PPN & Target Crops & References \\
\hline Bacillus polymyxa & Meloidogyne incognita & Tomato & Khan and Akram, 2000 [103] \\
\hline Bacillus tequilensis & Meloidogyne incognita & Basil & Tiwari et al., 2017 [100] \\
\hline Burkholderia cepacia & Meloidogyne incognita & Tomato & Meyer et al., 2000 [104] \\
\hline $\begin{array}{l}\text { Lysinibacillus } \\
\text { sphaericus }\end{array}$ & Meloidogyne incognita & Tomato & Colagiero et al., 2018 [105] \\
\hline Lysobacter spp. & Meloidogyne incognita & Tomato & Zhou et al., 2016 [102] \\
\hline $\begin{array}{l}\text { Paenibacillus } \\
\text { lentimorbus, } \\
\text { Paenibacillus polymyxa }\end{array}$ & Meloidogyne incognita & Tomato & Son et al., 2009 [106] \\
\hline Paenibacillus macerans & Meloidogyne exigua & Coffee & Oliveira et al., 2007 [107] \\
\hline $\begin{array}{l}\text { Pseudomonas } \\
\text { solanacearum }\end{array}$ & Rotylenchulus reniformis & Eggplant & Kermarrec et al.,1994 [108] \\
\hline Pseudomonas striata & Meloidogyne incognita & Pea & Siddiqui and Singh, 2005 [109] \\
\hline Pseudomonas stutzeri & Meloidogyne incognita & Chickpea & Seenivasan et al., 2001 [110] \\
\hline $\begin{array}{l}\text { Stenotrophomonas } \\
\text { maltophilia }\end{array}$ & $\begin{array}{l}\text { Paratrichodorus } \\
\text { pachydermus, Trichodorus } \\
\text { primitious }\end{array}$ & Potato & Insunza et al., 2002 [111] \\
\hline Streptomyces spp. & Meloidogyne incognita & Eggplant, Tomato & Rashad et al., 2015 [112] \\
\hline
\end{tabular}

\section{Recent Increases in Agronomic Burden by PPN}

PPN, microscopic roundworms, belonging to the phylum Nematoda that are among the most abundant animal on earth; over 4100 species have been found in a variety of environmental conditions. The majority of PPN live in the film of moisture surrounding soil particles and plant roots. PPN have protrusible stylets or mouth spear to enter root tissues [1]. On the basis of their feeding habitats, PPN are chiefly classified into two groups, ectoparasites, and endoparasites. Ectoparasites feed from the outside of root surfaces without entering into plant roots. Thus, they could be more susceptible to environmental stresses and predators, and causing lesser damage to plant roots, than endoparasites. Endoparasites are able to penetrate completely or partly into plant roots during the infection process. This causes physical injury as well as allows secondary damages by bacteria and fungi infected along with or after PPN [113]. Damages caused by endoparasitic nematodes including Meloidogyne spp. (root-knot nematodes; RKN), Heterodera spp., Globodera spp. (cyst nematodes), Pratylenchus spp. (lesion nematodes), and Rotylenchulus spp. (reniform nematodes) are estimated to result in an annual loss of $\sim 13 \%$ ( $\sim 216$ billion) worldwide [114]. For instance, two genera of PPN, Meloidogyne spp. and Heterodera spp., alone cause the $\sim 10 \%$ reduction of major food production including wheat (Triticum aestivum L.), rice (Oryza sativa L.), corn, potato, and sweet potato (Ipomoea batatas L.), which totaled an estimated loss of $\sim \$ 80$ to 114 billion per year. Rotylenchulus spp. has also emerged as a major threat in cash crops, cotton, and soybean, over the last decade throughout the southern regions of the US causing an estimated yield loss of over \$200 million annually [1,115-117]. Hence, the establishment of effective and sustainable management program to control PPN has become an urgent task across the nations. However, current methods of integrated PPN management are rather restricted, when compared to that for other insect and animal pests, because PPN are microscopic and generally attack the underground portion of plants. The damage caused by PPN also are often not correctly identified because the aboveground symptoms mimic other diseases and environmental root-limiting factors delaying proper management $[118,119]$. 


\section{Current Management Method against PPN}

The current integrated pest management (IPM) program aimed at PPN largely strategizes the combined uses of crop rotation, tolerant/resistant cultivars, and nematicides. These methods, however, are still inadequate, expensive and/or cause numerous unexpected ecological and social drawbacks $[120,121]$. Presently, the most common strategy to manage PPN infections and field infestations is the application of nematicides (e.g., aldicarb, fluazaindolizine, fluensulfone, fluopyram, oxamyl, and terbufos) [122,123]. Nematicides have been an effective management tool; however, chemical nematicides are harmful to the environment, dangerous to apply and very costly [118]. Therefore, crop rotation has long been recommended as an alternative and potentially effective cultural practice to reduce nematode population density [5], but is not be a feasible option for all crops and farmers. For example, in the southern areas of the US, one of the most efficient crop rotations schemes for RKN, Meloidogyne incognita (Kafoid and White, 1919) [124] infested fields include the nonhost crop of peanut (Arachis hypogaea L.) [5,125]. However, peanuts require different harvesting equipment compared to cotton, soybeans, and corn, the most prominent row crops in the region. This harvesting equipment can range into the hundreds of thousands of dollars, and therefore may not be an economically feasible strategy.

Resistant cultivars increasingly have become available, preventing PPN from reproducing at as high a level as with susceptible cultivars; however, these cultivars are often accompanied by decreased yield [126]. Thus, some groups have advocated the use of tolerant cultivars that do not decrease the PPN reproduction but have little effect on yield potential [127]. The crucial drawback of tolerant cultivars though is that they cause an increase in the field population density of PPN. Thus, the use of resistant and tolerant cultivars is the most successful when used as a part of IPM system. Hence, alternative strategies must be looked at for effective, sustainable management of PPN. One, emerging option is biological control, which encompasses beneficial microbes such as PGPR that can reduce the impact of PPN, and other biotic attackers and abiotic stresses, as well as synergistically help the plant enhancing growth and development of various plant species [8].

\section{Current utility of PGPR as BCAs of PPN; Mode of actions of PGPR}

Recent studies have proposed that biological control could be a cost-effective approach to manage PPN when compared to the conventional methods. Especially, PGPR have emerged as promising BCA candidates [128,129]. PGPR are non-pathogenic bacteria, known to enhance plant growth and development in both non-stressed and stressed conditions by direct and indirect mechanisms [130]. The direct mechanism describes PGPR as bio-fertilizers producing organic compounds that promote plant growth or increase uptake of soil nutrients. Indirect mechanisms refer to PGPR-dependent biocontrol, including the production of antibiotics, Fe chelators (called as siderophores), and external cell wall degrading enzymes (e.g., chitinase and glucanase) that perhaps hydrolyze the pathogen (i.e., fungus) cell wall [131]. In line with this scenario, a number of PGPR, frequently from the genera of Agrobacterium, Bacillus, Paenibacillus and Pseudomonas, have been documented to reduce PPN population density through different mechanisms like parasitism, production of hydrolytic enzymes and antinematicidal metabolites (direct antagonism; Table 1), and inducing systemic resistance (indirect antagonism; Table 2) [130].

\subsection{Direct Antagonism of PGPR against PPN}

Direct antagonism of PGPR can prevent egg hatch, and/or the growth and reproduction of PPN, mainly through predation, and release of toxins or hydrolytic enzymes including hydrogen cyanide (HCN), 2,4-diacetylphloroglucinol (DAPG), chitinases, glucanases, proteases, and lipases (Table 1). The best characterized, although not necessarily PGPR, predatory bacterium is Pasteuria penetrans (ex Thorne, 1940) [42], which directly attacks and colonizes the body cavity of RKN (Meloidogyne spp.). Once attached on the cuticle surface of RKN, P. penetrans spores begin to form germination tubes that 
penetrate and rupture the cell membrane of PPN [132]. Likewise, P. thornei [133] can attack root-lesion nematodes (RLN, Pratylenchus spp.) and P. nishizawae [45] is able to attack the cysts nematode of two genera, Heterodera spp., and Globodera spp. [44].

Indeed, the exogenous application of P. penetrans demonstrated drastic decreases in the population density of M. javanica (Treub, 1885) [123] in sugarcane (Saccharum officinarum L.), by an average of 97.5\% [43]. Thus, a few Pasteuria spp. have been made into commercial products; e.g., Clariva pn, Naviva ST and NewPro (Table 3). However, these products appear to be only active on one or two target species limiting actual practicality and use for field conditions. Producers often look for products that confer a broader spectrum of disease resistance, as well as defense responses against PPN.

On the other hand, a number of PGPR belonging to Bacillus spp. and Pseudomonas spp. produce nematicidal compounds. For example, several strains of Pseudomonas fluorescens (Flüge, 1886) [134] reduce potato cyst nematodes (PCN, Globodera spp.) and RKN (M. incognita) levels in vitro and/or in soil conditions by releasing DAPG, a phenolic antiphytopathogenic metabolite [49]. The wild type (WT) bacterium can reduce the motility of juvenile PCNs by $85 \%$, comparing to $27 \%$ by mutant strains that disrupted DAPG productions [49]. On the other hand, P. fluorescens strain CHA0 and P. aeruginosa (Schröter, 1872) [135] produce the volatile compound HCN, an extremely poisonous toxin that adversely affects the proper functions and formations of mitochondria in serval RKN spp. (e.g., M. incognita and M. javanica) [46,50]. Interestingly, P. fluorescens strain CHA0 also releases both DAPG and pyoluteorin, two secondary metabolites that can significantly decrease population density of M. javanica in vitro and in a soil setting $[51,53]$.

Several hydrolytic enzymes produced by PGPR are also able to inhibit the synthesis and maintenance of cell walls and membranes, as well as prevent the formation of cellular organelles [136]. Chitinases and discrete proteolytic enzymes produced from Bacillus cereus [137], B. firmus [138], B. licheniformis (Weigmann, 1898) [139], B. megaterium [140], and B. subtilis (Ehrenberg 1835) [141], as well as Corynebacterium paurometabolu [142] are proposed to be responsible for suppressing the multiplication of diverse RKN and cysts nematodes (see Table 1).

However, current attempts to commercialize PGPR for PPN management has had limited success [143]. A major concern has been that PGPR is inconsistent in managing PPN in the field, possibly due to many endogenous and exogenous factors limiting PGPR root colonization. Factors include other plants, variable soil conditions, and various rhizospheric metabolites and organisms [144]. Thus, there is a need to further investigate enhancing and/or optimizing the BCA activity of PGPR. Many studies now have turned into investigate the ability and a potential efficacy of indirect antagonism (i.e., ISR) of PGPR against PPN as an alternative, practical way to ensure the improvement of the defense capacity of plants against PPN, as well as other pathogens and abiotic constraints, and concurrently to enhance plant growth and development.

\subsection{Indirect Antagonism, ISR of PGPR against PPN}

Indirect antagonism of PGPR against PPN that occurs by ISR, is also referred to as PGPR-mediated priming, which systematically equips the "whole" plants to better cope with environmental constraints, actuating faster and/or stronger defense responses (adaption) to a subsequent exposure to various biotic and abiotic stresses. ISR is nonspecific in nature, and provides plants "a long-lasting protection" and "a broad-spectrum disease resistance (defense responses)" against various pathogenic microbes, insect herbivores and pests including PPNs; e.g., M. incognita, M. javanica, Heterodera glycines [145], H. cajani [146] and Globodera pallida [147] Behrens, 1975 (Table 2) [6]. In fact, ISR developed by various Bacillus spp. and Pseudomonas spp., including B. subtilis, B. amyloliquefaciens (ex Fukumoto, 1943) [148] and P. fluorescens have demonstrated promising results suppressing PPN in both dicotyledonous (Arabidopsis, bean (Fabaceae spp.), carnation (Dianthus caryophyllus L.), cucumber (Cucumis sativus L.), radish (Raphanus sativus L.), tobacco (Nicotiana tabacum L.), and tomato (Solanum lycopersicum L.)) as well as monocotyledonous (rice, maize, and sugarcane) plants (see Table 2). 
However, molecular mechanisms underlying its occurrences are still elusive. Thus far, a majority of studies have foregrounded the potential, functional relevance of JA and ET hormones in ISR development, as mutant plants disrupted in JA/ET biosynthesis or signaling exhibited impaired PGPR-induced priming (reviewed in [6]). Moreover, exogenous application of JA could demonstrate ISR development against RKN (e.g., M. incognita, M. graminicola [149], and M javanica), cyst nematodes (e.g., H. avenae (Wollenweber, 1924) [150], H. schachtii [151]), and root lesion nematode (Pratylenchus neglectus (Rensch, 1924) [152]) in various plant species [153,154]. However, the root colonization of PGPR did not appear to stimulate the production of JA/ET in systemic (leaf) tissues, nor did they induce the expression of JA/ET-responsive genes in leaves $[155,156]$. Instead, ISR could potentiate JA/ET-responsive genes. When plants exposed/treated with PGPR were later challenged with other biotic stressors (e.g., microbial pathogens, insects, or herbivores), ISR facilitated a more rapid and/or enhanced level of induction of JA/ET-responsive genes, VSP, PDF1.2, and HEL [156,157].

On the other hand, selective results from earlier studies argued otherwise. Root inoculations of PGPR immediately triggered JA production and signaling transductions in systemic (leaf) tissues, which in turn heighted the state of defense responses throughout the plant [158]. Inoculation of PGPR Serrattia marcescens (Bizio, 1823) [159] strain 90-166 and P. fluorescens WCS417r showed rapid upregulation of several JA-biosynthetic and -responsive genes, e.g., VSP, PDF1.2, HEL, ChiB, LOX, and PAL in systemic (leaf) tissue throughout a number of crop plants, as well as Arabidopsis [61,160]. JA production then coordinates with abscisic acid (ABA) signaling to activate selective stress-responsive transcription factors such as OCP3 (Overexpressor of Cationic Peroxidase 3) and MYB60 [161,162], which in turn regulate stomatal closure, and suppress plant growth and yield [163]. These signaling and metabolic cascades may explain the inhibitory effect of JA in plant growth and development [164]. Indeed, the exogenous application of JA characteristically results in the inhibition of root growth $[6,165,166]$, together suggesting that (i) ISR (and PGPR-induced JA signaling) could compete resource allocations (namely, defense and growth tradeoffs) with PGPR-mediated growth enhancement, or (ii) ISR employs alternative and/or additional (besides JA-responsive) signaling and/or metabolic pathways to prime plant disease resistance without reducing yield potential.

\subsection{Potential Roles of $S A$ in the Indirect Antagonism, SAR of PGPR against PPN}

Recently, selective data argues that PGPR could stimulate SAR (instead of ISR), widely known to be developed by pathogenic microbes but not by PGPR $[7,131]$. The caveat is that ISR and SAR require mutually antagonistic cellular mechanisms, JA signaling for ISR versus SA signaling for SAR [6,7], which initially conflicted the role of SAR and SA signaling in the indirect antagonism of PGPR. However, a few studies reported that several Bacillus spp. can stimulate SA accumulations and signaling in plants (Table 2), hypothesizing that a mode of ISR mimics or shares SAR mechanisms. For instance, B. amyloliquefaciens MBI600, active ingredient of the biological fungicide Serifel ${ }^{\circledR}$, was characterized to activate SA-dependent, but JA-independent, immunity, and reduce the disease severity of tomato spotted wilt virus in tomatoes [61]. It is notable that independent studies from other groups using similar PGPR strains such as B. amyloliquefaciens, B. mycoides (Flugge, 1886) [167], B. pumilus (Meyer and Gottheil, 1901) [168], and B. subtilis reported an induction of JA signaling (see Table 2). The cause for this contradiction is not understood, but may result from different experimental conditions and/or experimental errors. Alternatively, there may be timing differences to induce JA or SA signaling by PGPR (JA first and SA latter). A recent study using time-resolved transcription analyses indicated that the inoculation of Trichoderma harzianum (Rifai, 1969) [169] rapidly activates JA signaling on a time scale of hours, but later switches to enhance SA activity in 3 to 7 days in both infected and systemic tissues of plants [89]. This finding suggests the presence of complex and/or alternative mechanisms in PGPR-mediated systemic resistance. Further investigations must clarify the combined or antagonistic roles and functions of different plant hormone signaling such as JA, ET, SA, and ABA [170] in conveying defense activation by PGPR. 


\subsection{Crosstalk between SA and JA Signaling}

As alluded, JA and SA signaling crosstalk with each other [171,172], and these interactions can be either antagonistic or synergistic. One of the first investigations into their interaction revealed an antagonistic relationship between JA and SA in tomatoes. They observed that aspirin, formulated SA, significantly suppressed the expression of JA marker genes [173]. Similarly, the expression of SA marker genes was inhibited upon the stimulation of JA by Pseudomonas syringae in tomato [174]. Furthermore, the application of exogenous JA also correlated with decreased SA activity, and enhanced JA signaling [175]. A more in depth look into the antagonism demonstrated that SA signaling targets the downstream of promoter in JA-responsive genes, and inhibits any further JA activity [176]. It is hypothesized that the antagonism be-tween the two hormones (JA and SA) helps plants conserve energy, and optimize the defense pathways in the presence of a single pathogen [171,172].

In contrast, a few early studies suggested a potential, synergistic relationship between JA and SA, as the pathogens Botrytis cinerea (Persoon, 1794) [177] and Tobacco mosaic virus stimulate both JA and SA at the same time $[178,179]$. Mur et al. later suggested that the concentration of hormones determined the interaction between them [180]. If the level of JA or SA is too high there was an antagonistic relationship; however, if the levels of each hormone were lower, the two hormones acted synergistically [180]. The exact concentration where synergism between the two hormones turns to antagonism is yet to be determined.

The goal of biological control research is to optimize the BCA to be as effective and efficient as possible against the target pathogen(s), and determining any manipulation of the JA and SA pathways by the target pathogen is an essential part of this type of research. This can, in turn, determine the best pathway to provide the most effective protection and defense against the target pathogen. This is important to keep in mind when selecting the best BCA in each management strategy.

\section{Commercialization of PGPR}

There is still a fundamental question (i.e., reproducibility) to address for the commercialization of PGPR, though multiple strains of PGPR are available on the market as biological nematicides (Table 3). However, the efficacy of these products needs to be further evaluated. To be commercially successful, PGPR products should have a broad application, long shelf life, be safe to use, have a viable market, easy availability, be consistent and have a low investment cost. Indeed, a large number of PGPR strains still remain to be investigated (Table 4). One particularly noticeable genus of PGPR is Bacillus spp. (9 direct antagonism, 7 indirect antagonism, and 17 uncharacterized); considered to be good options because they can quickly replicate and colonize plants, tolerate harsher environments, and easily form endospores. Moreover, they are documented to affect a broad spectrum of plant pathogens including PPN, viruses, bacteria, and fungi [181]. An extra benefit is that many of these Bacillus spp. can promote plant growth and help the plant adapt abiotic stresses, enhancing yield potential [182,183]. Bacillus spp. are the main species of commercialized PGPR due to their hardiness, as described above, compared to other effective PGPR such as Pseudomonas spp. [184]. More studies however are required to assess more effective mechanisms of their modus operandi as BCAs of PPN.

\section{Conclusions}

Emerging results have proposed the potential use and value of PGPR as BCAs in managing PPN. Selective strains of PGPR, in particular many Bacillus spp. appear to effectively suppress the growth and infestation of PPN in plants and fields, via direct or indirect antagonistic mechanism. Initially, much effort was invested to isolate (1) predatory PGPR strains and/or (2) PGPR-released nematicidal toxins and hydrolytic enzymes, which readily kill or inhibit PPN. However, their products were often highly host-specific, limiting actual use and practicality for field applications. Thus, recent studies have tried to understand, and improve the indirect antagonism (ISR) of PGPR, especially since PGPR have (i) longer shelf life, (ii) easy availability, (iii) low investment- and production-cost, and are (iv) safe 
to use. Moreover, PGPR are (v) effective biostimulants facilitating plant growth and yield potential, as well as are able to (vi) enhance plant resistance against a broad range of microbial pathogens, pests, and insect herbivores (i.e., ISR), and (vii) concurrently prime plants to better adapt or acclimate towards various abiotic stresses including drought, salinity, and extreme temperatures. These multifaceted activities, and benefits clearly underpin important merits and practicality for further screening and accessing the activity and efficacy of new PGPR in managing economically damaging PPN. Successful development/commercialization of BCAs will greatly aid in upgrading plants' own survival capacity against various ecological constraints, but without trading off yield potential.

Author Contributions: Writing—original draft preparation, P.S., K.G., and S.-W.P.; writing—review and editing, W.L., K.S.L., and S.-W.P.; and funding acquisition, K.S.L. and S.-W.P. All authors have read and agreed to the published version of the manuscript.

Funding: This research was supported in part by the Alabama Cotton Commission, the Alabama Agricultural Experiment Station, and the Hatch program of the National Institute of Food and Agriculture (USDA).

Acknowledgments: The authors thank P. Donald and J. Coleman for critical comment on the manuscript.

Conflicts of Interest: The authors declare no conflict of interest.

\section{References}

1. Nicol, J.M.; Turner, S.J.; Coyne, D.L.; den Nijs, L.; Hockland, S.; Maafi, Z.T. Current nematode threats to world agriculture. In Genomics and Molecular Genetics of Plant-Nematode Interaction; Jones, J., Gheyse, G., Ffenoll, C., Eds.; Springer: Berlin/Heidelberg, Germany, 2011; pp. 21-43.

2. Aktar, M.W.; Sengupta, D.; Chowdhury, A. Impact of pesticides use in agriculture: Their benefits and hazards. Interdiscip. Toxicol. 2009, 2, 1-12. [CrossRef] [PubMed]

3. Timper, P. Conserving and enhancing biological control of nematodes. J. Nematol. 2014, 46, 75-89. [PubMed]

4. Xiang, N.; Lawrence, K.; Donald, P. Biological control potential of plant growth-promoting rhizobacteria suppression of Meloidogyne incognita on cotton and Heterodera glycines on soybean: A review. J. Phytopathol. 2018, 166, 449-458. [CrossRef]

5. Kirkpatrick, T.L.; Sasser, J.N. Crop rotation and races of Meloidogyne incognita in cotton root-knot management. J. Nematol. 1984, 16, 323-328. [PubMed]

6. Pieterse, C.M.J.; Zamioudis, C.; Berendsen, R.L.; Weller, D.M.; van Wees, S.C.M.; Bakker, P.A.H.M. Induced systemic resistance by beneficial microbes. Annu. Rev. Phytopathol. 2014, 52, 347-375. [CrossRef] [PubMed]

7. Vlot, A.C.; Klessig, D.F.; Park, S.W. Systemic acquired resistance: The elusive signal(s). Curr. Opin. Plant Biol. 2008, 11, 436-442. [CrossRef]

8. De Vrieze, J. The littlest farmhands. Science 2015, 349, 680-683. [CrossRef]

9. Oka, Y.; Chet, I.; Spiegel, Y. Control of the rootknot nematode Meloidogyne javanica by Bacillus cereus. Biocontrol Sci. Technol. 1993, 3, 115-126. [CrossRef]

10. Gao, H.; Qi, G.; Yin, R.; Zhang, H.; Li, C.; Zhao, X. Bacillus cereus strain S2 shows high nematicidal activity against Meloidogyne incognita by producing sphingosine. Sci. Rep. 2016, 6, 28756. [CrossRef]

11. Ahmed, S. Bacillus cereus a potential strain infested cereal cyst nematode (Heterodera avenae). Pak. J. Nematol. 2019, 37, 53-61. [CrossRef]

12. Ambo, P.B.N.; Ethiopia, E.A.; Serfoji, P.; Rajeshkumar, S.; Selvaraj, T. Management of root-knot nematode, Meloidogyne incognita on tomato cv Pusa Ruby by using vermicompost, AM fungus, Glomus aggregatum and mycorrhiza helper bacterium, Bacillus coagulans. J. Agric. Sci. Technol. 2010, 6, 37-45.

13. Serfoji, P.; Smithra, P.; Saravavanan, K.; Durai Raj, K. Plant growth promotion and management of root-knot nematode Meloidogyne incognita through Glomus aggregatum and Bacillus coagulans and vermicomposting in tomato. Int. J. Pharm. Biol. Arch. 2013, 4, 532-536.

14. Giannakou, I.O.; Karpouzas, D.G.; Prophetou-Athanasiadou, D. A novel non-chemical nematicide for the control of root-knot nematodes. Appl. Soil Ecol. 2004, 26, 69-79. [CrossRef]

15. Mendoza, A.R.; Kiewnick, S.; Sikora, R.A. In vitro activity of Bacillus firmus against the burrowing nematode Radopholus similis, the root-knot nematode Meloidogyne incognita and the stem nematode Ditylenchus dipsaci. Biocontrol Sci. Technol. 2008, 18, 377-389. [CrossRef] 
16. Terefe, M.; Tefera, T.; Sakhuja, P.K. Effect of a formulation of Bacillus firmus on root-knot nematode Meloidogyne incognita infestation and the growth of tomato plants in the greenhouse and nursery. J. Invertebr. Pathol. 2009, 100, 94-99. [CrossRef]

17. Terefe, M.; Tefera, T.; Sakhuja, P.K. Biocontrol (formulation of Bacillus firmus (BioNem)) of root-knot nematode, Meloidogyne incognita on tomato plants in the field. Ethiop. J. Agric. Sci. 2012, 22, 102-116.

18. Xiong, J.; Zhou, Q.; Luo, H.; Xia, L.; Li, L.; Sun, M.; Yu, Z. Systemic nematicidal activity and biocontrol efficacy of Bacillus firmus against the root-knot nematode Meloidogyne incognita. World J. Microbiol. Biotechnol. 2015, 31, 661-667. [CrossRef]

19. Geng, C.; Nie, X.; Tang, Z.; Zhang, Y.; Lin, J.; Sun, M.; Peng, D. A novel serine protease, Sep1, from Bacillus firmus DS-1 has nematicidal activity and degrades multiple intestinal-associated nematode proteins. Sci Rep. 2016, 6, 25012. [CrossRef]

20. Bayer Crop Science. Available online: www.cropscience.bayer.us/products/seedgrowth/ponchovotivo/ (accessed on 18 August 2020).

21. Siddiqui, Z.A.; Husain, S.I. Studies on the biological control of root-knot nematode. Curr. Nematol. 1991, 2, 5-6.

22. Siddiqui, Z.A.; Mahmood, I. Biological control of root-rot disease complex of chickpea caused by Meloidogyne incognita Race 3 and Macrophomina phaseolina. Nematol. Medit. 1992, 20, 199-202.

23. Jeong, M.-H.; Yang, S.-Y.; Lee, Y.-S.; Ahn, Y.-S.; Park, Y.-S.; Han, H.; Kim, K.-Y. Selection and characterization of Bacillus licheniformis MH48 for the biocontrol of pine wood nematode (Bursaphelenchus xylophilus). J. Korean For. Soc. 2015, 104, 512-518. [CrossRef]

24. El-Nagdi, W.M.A.; Abd-El-Khair, H.; Soliman, G.M.; Ameen, H.H.; El-Sayed, G.M. Application of protoplast fusants of Bacillus licheniformis and Pseudomonas aeruginosa on Meloidogyne incognita in tomato and eggplant. Middle East J. Appl. Sci. 2019, 9, 622-629.

25. Kloepper, J.W.; Beauchamp, C.J. A review of issues related to measuring of plant roots by bacteria. Can. J. Microbiol. 1992, 38, 1219-1232. [CrossRef]

26. Padgham, J.L.; Sikora, R.A. Biological control potential and modes of action of Bacillus megaterium against Meloidogyne graminicola on rice. Crop Prot. 2007, 26, 971-977. [CrossRef]

27. Mostafa, F.A.M.; Khalil, A.E.; Nour El-Deen, A.H.; Ibrahim, D.S. The role of Bacillus megaterium and other bio-agents in controlling root-knot nematodes infecting sugar beet under field conditions. Egypt. J. Biol. Pest Control 2018, 28, 66. [CrossRef]

28. Lee, Y.S.; Kim, K.Y. Antagonistic potential of Bacillus pumilus L1 against root-knot nematode, Meloidogyne arenaria. J. Phytopathol. 2016, 164, 29-39. [CrossRef]

29. Forghani, F.; Hajihassani, A. Recent advances in the development of environmentally benign treatments to control root-knot nematodes. Front. Plant Sci. 2020, 11, 1125. [CrossRef]

30. Prakob, W.; Nguen-Hom, J.; Jaimasit, P.; Thanunchai, J.; Chaisuk, P. Biological control of lettuce root-knot disease by the used of Pseudomonas aeruginosa, Bacillus subtilis and Paecilomyces lilacinus. J. Agric. Technol. 2009, 13, 179-191.

31. Kavitha, P.G.; Jonathan, E.L.; Nakkeeran, S. Effects of crude antibiotic of Bacillus subtilis on hatching of eggs and mortality of juveniles of Meloidogyne incognita. Nematol. Mediterr. 2012, 40, 211-215.

32. Basyony, A.G.; Abo-Zaid, G.A. Biocontrol of the root-knot nematode, Meloidogyne incognita, using an eco-friendly formulation from Bacillus subtilis, lab and greenhouse studies. Egypt. J. Biol. Pest Control 2018, 28, 87. [CrossRef]

33. de Mazzuchelli, R.C.L.; Mazzuchelli, E.H.L.; de Araujo, F.F. Efficiency of Bacillus subtilis for root-knot and lesion nematodes management in sugarcane. Biol. Control 2020, 143, 104185. [CrossRef]

34. Gautam, A.; Siddiqui, Z.; Mahmood, I. Integrated management of Meloidogyne incognita on tomato. Nematol. Mediterr. 1995, 23, 245-248.

35. Noel, G.R. Evaluation of thuringiensin for control of Heterodera glycines on soybean. J. Nematol. 1990, 22, 763-766. [PubMed]

36. Wei, J.-Z.; Hale, K.; Carta, L.; Platzer, E.; Wong, C.; Fang, S.-C.; Aroian, R.V. Bacillus thuringiensis crystal proteins that target nematodes. Proc. Natl. Acad. Sci. USA 2003, 100, 2760-2765. [CrossRef]

37. Mohammed, S.; Saedy, M.; Enan, M.; Ibrahim, N.E.; Ghareeb, A.; Moustafa, S. Biocontrol efficiency of Bacillus thuringiensis toxins against root-knot nematode, Meloidogyne incognita. J. Cell Mol. Biol. 2008, 7, 57-66. 
38. Mena, J.; Pimentel, E. Mechanism of action of Corynebacterium pauronetabolum strain C-924 on nematodes. Nematology 2002, 4, 287.

39. Mankau, R.; Imbriani, J.L.; Bell, A.H. SEM observations on nematode cuticle penetration by Bacillus penetrans. J. Nematol. 1976, 8, 179-181.

40. Mankau, R.; Prasad, N. Possibilities and problems in use of a sporozoan endoparasite for biological control of plant parasitic nematodes. Nematropica 1977, 2, 7-8.

41. Dube, B.; Smart, G.C. Biological control of Meloidogyne incognita by Paecilomyces lilacinus and Pasteuria penetrans. J. Nematol. 1987, 19, 222-227.

42. Sayre, R.M.; Starr, M.P. Pasteuria penetrans a mycelial and endospore-forming bacterium parasitic in plant-parasitic nematodes. Proc. Helminthol. Soc. Wash 1985, 52, 149-165.

43. Bhuiyan, S.A.; Garlick, K.; Anderson, J.M.; Wickramasinghe, P.; Stirling, G.R. Biological control of root-knot nematode on sugarcane in soil naturally or artificially infested with Pasteuria penetrans. Australas. Plant Pathol. 2018, 47, 45-52. [CrossRef]

44. Atibalentja, N.; Noel, G.R.; Domier, L.L. Phylogenetic position of the North American isolate of Pasteuria that parasitizes the soybean cyst nematode, Heterodera glycines, as inferred from 16S RDNA sequence analy-sis. Int. J. Syst. Evol. Microbiol. 2000, 50, 605-613. [CrossRef] [PubMed]

45. Sayre, R.M.; Wergin, W.P.; Schmldt, J.M.; Starr, M.P. Pasteuria nishizawae sp. nov., a mycelial and endospore-forming bacterium parasitic on cyst nematodes of genera Heterodera and Globodera. Res. Microbiol. 1991, 142, 551-564. [CrossRef]

46. Siddiqui, I.A.; Ehteshamul-Haque, S. Suppression of the root rot-root knot disease complex by Pseudomo-nas aeruginosa in tomato: The influence of inoculum density, nematode populations, moisture and other plant-associated bacteria. Plant Soil 2001, 237, 81-89. [CrossRef]

47. Gallagher, L.A.; Manoil, C. Pseudomonas aeruginosa PAO1 kills Caenorhabditis elegans by cyanide poisoning. J. Bacteriol. 2001, 183, 6207-6214. [CrossRef]

48. Singh, P.; Siddiqui, Z.A. Biocontrol of root-knot nematode Meloidogyne incognita by the isolates of Pseudomonas on tomato. Arch. Phytopathol. Plant Protect. 2010, 43, 1423-1434. [CrossRef]

49. Cronin, D.; Moenne-Loccoz, Y.; Fenton, A.; Dunne, C.; Dowling, D.N.; O'gara, F. Role of 2,4-diacetyl-phloroglucinol in the interactions of the biocontrol Pseudomonad strain F113 with the potato cyst nematode Globodera rostochiensis. Appl. Environ. Microbiol. 1997, 63, 1357-1361. [CrossRef]

50. Siddiqui, I.; Shaukat, S. Suppression of root-knot disease by Pseudomonas fluorescens CHA0 in tomato: Importance of bacterial secondary metabolite, 2,4-diacetylpholoroglucinol. Soil Biol. Biochem. 2003, 35, 1615-1623. [CrossRef]

51. Hamid, M.; Siddiqui, I.A.; Shahid Shaukat, S. Improvement of Pseudomonas fluorescens CHA0 biocontrol activity against root-knot nematode by the addition of ammonium molybdate. Lett. Appl. Microbiol. 2003, 36, 239-244. [CrossRef]

52. Siddiqui, I.A.; Haas, D.; Heeb, S. Extracellular protease of Pseudomonas fluorescens CHA0, a biocontrol factor with activity against the root-knot nematode Meloidogyne incognita. Appl. Environ. Microbiol. 2005, 71, 5646-5649. [CrossRef]

53. Timper, P.; Koné, D.; Yin, J.; Ji, P.; McSpadden Gardener, B.B. Evaluation of an antibiotic-producing strain of Pseudomonas fluorescens for suppression of plant-parasitic nematodes. J. Nematol. 2009, 41, 234-240.

54. Khan, M.R.; Mohidin, F.A.; Khan, U.; Ahamad, F. Native Pseudomonas spp. suppressed the root-knot nematode in in vitro and in vivo, and promoted the nodulation and grain yield in the field grown mungbean. Biol. Control 2016, 101, 159-168. [CrossRef]

55. Zabaketa-Mejia, E. The effect of soil bacteria on Meloidogyne incognita (Kofoid \& White) Chitwood infection. Diss. Abstr. Interact. 1985, 46, 1018.

56. Rahul, S.; Chandrashekhar, P.; Hemant, B.; Chandrakant, N.; Laxmikant, S.; Satish, P. Nematicidal activity of microbial pigment from Serratia marcescens. Nat. Prod. Res. 2014, 28, 1399-1404. [CrossRef] [PubMed]

57. Hasky-Guenther, K.; Hoffmann-Hergarten, S.; Sikora, R.A. Resistance against the potato cyst nematode Globodera pallida systemically induced by the rhizobacteria Agrobacterium radiobacter (G12) and Bacillus sphaericus (B43). Fundam. Appl. Nematol. 1998, 21, 511-517.

58. Hackenberg, C.; Sikora, R.A. Influence of cultivar, temperature, and soil moisture on the antagonistic potential of Agrobacterium radiobacter against Globodera pallida. J. Nematol. 1992, 24, 594. 
59. Racke, J.; Sikora, R.A. Influence of the plant health-promoting rhizobacteria Agrobacterium radiobacter and Bacillus sphaericus on Globodera pallida root infection of potato and subsequent plant growth. J. Phytopathol. 1992, 134, 198-208. [CrossRef]

60. Hackenberg, C.; Vrain, T.C.; Sikora, R.A. Rhizosphere colonization pattern of Agrobacterium Radiobacter strain G12A, an antagonistic rhizobacterium to the potato cyst nematode Globodera pallida. Microbiol. Res. 1999, 154, 57-61. [CrossRef]

61. Ryu, C.-M.; Farag, M.A.; Hu, C.-H.; Reddy, M.S.; Kloepper, J.W.; Paré, P.W. Bacterial volatiles induce systemic resistance in Arabidopsis. Plant Physiol. 2004, 134, 1017-1026. [CrossRef]

62. Beris, D.; Theologidis, I.; Skandalis, N.; Vassilakos, N. Bacillus amyloliquefaciens strain MBI600 induces Sali-cylic acid dependent resistance in tomato plants against tomato spotted wilt virus and potato virus $\mathrm{Y}$. Sci. Rep. 2018, 8, 10320. [CrossRef]

63. Burkett-Cadena, M.; Kokalis-Burelle, N.; Lawrence, K.S.; van Santen, E.; Kloepper, J.W. Suppressiveness of root-knot nematodes mediated by rhizobacteria. Biol. Control. 2008, 47, 55-59. [CrossRef]

64. Choudhary, D.K.; Johri, B.N. Interactions of Bacillus spp. and plants-with special reference to induced systemic resistance (ISR). Microbiol. Res. 2009, 164, 493-513. [CrossRef]

65. Li, J.; Zou, C.; Xu, J.; Ji, X.; Niu, X.; Yang, J.; Huang, X.; Zhang, K.-Q. Molecular mechanisms of nematode-nematophagous microbe interactions: Basis for biological control of plant-parasitic nematodes. Annu. Rev. Phytopathol. 2015, 53, 67-95. [CrossRef]

66. Xiang, N.; Lawrence, K.S.; Kloepper, J.W.; Donald, P.A.; McInroy, J.A.; Lawrence, G.W. Biological control of Meloidogyne incognita by spore-forming plant growth-promoting rhizobacteria on cotton. Plant Dis. 2016, 101, 774-784. [CrossRef] [PubMed]

67. Xie, S.; Jiang, H.; Ding, T.; Xu, Q.; Chai, W.; Cheng, B. Bacillus amyloliquefaciens FZB42 represses plant MiR846 to induce systemic resistance via a jasmonic acid-dependent signalling pathway. Mol. Plant Pathol. 2018, 19, 1612-1623. [CrossRef] [PubMed]

68. de Halfeld-Vieira, B.A.; Vieira Júnior, J.R.; da Romeiro, R.S.; Silva, H.S.A.; Baracat-Pereira, M.C. Induction of systemic resistance in tomato by the autochthonous phylloplane resident Bacillus cereus. Pesqui. Agropecu. Bras. 2006, 41, 1247-1252. [CrossRef]

69. Niu, D.-D.; Liu, H.-X.; Jiang, C.-H.; Wang, Y.-P.; Wang, Q.-Y.; Jin, H.-L.; Guo, J.-H. The plant growth-promoting rhizobacterium Bacillus cereus AR156 induces systemic resistance in Arabidopsis thaliana by simultaneously activating salicylate- and jasmonate/ethylene-dependent signaling pathways. Mol. Plant Microbe Interact. 2011, 24, 533-542. [CrossRef]

70. Jiang, C.; Fan, Z.; Li, Z.; Niu, D.; Li, Y.; Zheng, M.; Wang, Q.; Jin, H.; Guo, J. Bacillus cereus AR156 triggers induced systemic resistance against Pseudomonas syringae pv. tomato DC3000 by suppressing MiR472 and activating CNLs-mediated basal immunity in Arabidopsis. Mol. Plant Pathol. 2020, 21, 854-870. [CrossRef]

71. Liu, K.; Garrett, C.; Fadamiro, H.; Kloepper, J.W. Induction of systemic resistance in chinese cabbage against black rot by plant growth-promoting rhizobacteria. Biol. Control. 2016, 99, 8-13. [CrossRef]

72. Bargabus, R.L.; Zidack, N.; Sherwood, J.E.; Jacobsen, B.J. Characterisation of systemic resistance in sugar beet elicited by a non-pathogenic, phyllosphere-colonizing Bacillus mycoides biological control agent. Physiol. Mol. Plant Pathol. 2002, 61, 289-298. [CrossRef]

73. Ryu, C.-M.; Farag, M.A.; Hu, C.-H.; Reddy, M.S.; Wei, H.-X.; Paré, P.W.; Kloepper, J.W. Bacterial volatiles promote growth in Arabidopsis. Proc. Natl. Acad. Sci. USA 2003, 100, 4927-4932. [CrossRef] [PubMed]

74. Zhang, S.; Moyne, A.-L.; Reddy, M.S.; Kloepper, J.W. The role of salicylic acid in induced systemic resistance elicited by plant growth-promoting rhizobacteria against blue mold of tobacco. Biol. Control. 2002, 25, 288-296. [CrossRef]

75. Bargabus, R.; Zidack, N.; Sherwood, J.; Jacobsen, B. Screening for the identification of potential biological control agents that induce systemic acquired resistance in sugar beet. Biol. Control Biol. Control 2004, 30, 342-350. [CrossRef]

76. Kavitha, J.; Jonathan, E.I.; Umamaheswari, R. Field application of Pseudomonas fluorescens, Bacillus subtilis and Trichoderma viride for the control of Meloidogyne incognita (Kofoid and White) chitwood on sugarbeet. J. Biol. Control 2007, 21, 211-215.

77. Choudhary, D.K.; Prakash, A.; Johri, B.N. Induced systemic resistance (ISR) in plants: Mechanism of action. Indian J. Microbiol. 2007, 47, 289-297. [CrossRef] 
78. Lastochkina, O.; Pusenkova, L.; Yuldashev, R.; Babaev, M.; Garipova, S.; Blagova, D.; Khairullin, R.; Aliniaeifard, S. Effects of Bacillus subtilis on some physiological and biochemical parameters of Triticum aestivum L. (wheat) under salinity. Plant Physiol. Biochem. 2017, 121, 80-88. [CrossRef]

79. Akram, W.; Mahboob, A.; Javed, A.A. Bacillus thuringiensis strain 199 can induce systemic resistance in tomato against Fusarium wilt. Eur. J. Microbiol. Immunol. 2013, 3, 275-280. [CrossRef]

80. Zuckerman, B.M.; Dicklow, M.B.; Acosta, N. A strain of Bacillus thuringiensis for the control of plant-parasitic nematodes. Biocontrol Sci. Technol. 1993, 3, 41-46. [CrossRef]

81. Audenaert, K.; Pattery, T.; Cornelis, P.; Höfte, M. Induction of systemic resistance to Botrytis cinerea in tomato by Pseudomonas aeruginosa 7NSK2: Role of salicylic acid, pyochelin, and pyocyanin. Mol. Plant Microbe Interact. 2002, 15, 1147-1156. [CrossRef]

82. Fatima, S.; Anjum, T. Identification of a potential ISR determinant from Pseudomonas aeruginosa PM12 against Fusarium wilt in tomato. Front. Plant Sci. 2017, 8, 848. [CrossRef]

83. Krechel, A.; Faupel, A.; Hallmann, J.; Ulrich, A.; Berg, G. Potato-associated bacteria and their antagonistic potential towards plant-pathogenic fungi and the plant-parasitic nematode Meloidogyne incognita (Kofoid \& White) Chitwood. Can. J. Microbiol. 2002, 48, 772-786. [PubMed]

84. Saikia, S.K.; Tiwari, S.; Pandey, R. Rhizospheric biological weapons for growth enhancement and Meloidogyne incognita management in Withania somnifera cv. Poshita. Biol. Control. 2013, 65, 225-234. [CrossRef]

85. De Vleesschauwer, D.; Djavaheri, M.; Bakker, P.A.H.M.; Höfte, M. Pseudomonas fluorescens WCS374r-induced systemic resistance in rice against Magnaporthe oryzae is based on pseudobactin-mediated priming for a salicylic acid-repressible multifaceted defense response. Plant Physiol. 2008, 148, 1996-2012. [CrossRef] [PubMed]

86. Leeman, M.; van Pelt, J.A.; den Ouden, F.M.; Heinsbroek, M.; Bakker, P.A.H.M.; Schippers, B. Induction of systemic resistance by Pseudomonas fluorescens in radish cultivars differing in susceptibility to Fusarium wilt, using a novel bioassay. Eur. J. Plant Pathol. 1995, 101, 655-664. [CrossRef]

87. Almaghrabi, O.A.; Massoud, S.I.; Abdelmoneim, T.S. Influence of inoculation with plant growth promoting rhizobacteria (PGPR) on tomato plant growth and nematode reproduction under greenhouse conditions. Saudi J. Biol. Sci. 2013, 20, 57-61. [CrossRef] [PubMed]

88. Reitz, M.; Rudolph, K.; Schröder, I.; Hoffmann-Hergarten, S.; Hallmann, J.; Sikora, R.A. lipopolysaccharides of Rhizobium etli strain G12 act in potato roots as an inducing agent of systemic resistance to infection by the cyst nematode Globodera pallida. Appl. Environ. Microbiol. 2000, 66, 3515-3518. [CrossRef]

89. Martínez-Medina, A.; Fernandez, I.; Lok, G.B.; Pozo, M.J.; Pieterse, C.M.J.; Wees, S.C.M.V. Shifting from priming of salicylic acid- to jasmonic acid-regulated defences by Trichoderma protects tomato against the root knot nematode Meloidogyne incognita. New Phytol. 2017, 213, 1363-1377. [CrossRef]

90. BioNemaGonTM. Available online: http://www.agrilife.in/biopesti_microrigin_nemagon.htm (accessed on 18 August 2020).

91. Clariva®pn. Available online: https://www.syngenta-us.com/seed-treatment/clariva-pn (accessed on 18 August 2020).

92. Nematode: Alternative Controls. Available online: www.attra.ncat.org/attra-pub/PDF/nematode.pdf (accessed on 18 August 2020).

93. MeloConßWG. Available online: https://www.certisusa.com/products/bionematicides/melocon-wg (accessed on 18 August 2020).

94. Mistures Comprising a Bacillus Strain and a Pesticide. Available online: https://patentswarm.com/patents/ US10251400B2 (accessed on 18 August 2020).

95. US EPA, Pesticide Product Label, NewPro. Available online: https://www3.epa.gov/pesticides/chem_search/ ppls/085004-00011-20130422.pdf (accessed on 18 August 2020).

96. Nortica 10 WP. Available online: http://www.tomirwin.com/pdf/labels/Nortica\%2010WP.pdf (accessed on 18 August 2020).

97. VoTIVo FS. Available online: https://agrobaseapp.com/united-states/pesticide/votivo-fs (accessed on 18 August 2020).

98. Bansal, R.K.; Verma, V. kumar. Antagonistic efficacy of Azotobacter chroococcum against Meloidogyne javanica infecting brinjal. Indian J. Nematol. 2002, 32, 132-134.

99. Crow, W.T. Effects of a commercial formulation of Bacillus firmus I-1582 on golf course bermudagrass infested with Belonolaimus longicaudatus. J. Nematol. 2014, 46, 331-335. 
100. Tiwari, S.; Pandey, S.; Chauhan, P.; Pandey, R. Biocontrol agents in co-inoculation manages root knot nematode [Meloidogyne incognita (Kofoid \& White) Chitwood] and enhances essential oil content in Ocimum basilicum L. Ind. Crops Prod. 2017, 97, 292-301.

101. Siddiqui, Z.A.; Shakeel, U. Screening of Bacillus isolates for potential biocontrol of the wilt disease complex of pigeon pea (Cajanus cajan) under greenhouse and small-scale field conditions. J. Plant Pathol. 2007, 89, 179-183.

102. Zhou, L.; Yuen, G.; Wang, Y.; Wei, L.; Ji, G. Evaluation of bacterial biological control agents for control of rootknot nematode disease on tomato. Crop Prot. 2016, 84, 8-13. [CrossRef]

103. Khan, M.R.; Akram, M. Effect of certain antagonistic fungi and rhizobacteria on wilt disease complex caused by Meloidogyne incognita and Fusarium oxysporium f. sp. lycopersici on tomato. Nematol. Mediterr. 2000, 28, 139-144.

104. Meyer, S.L.F.; Massood, S.I.; Chitwood, D.J.; Roberts, D.P. Evaluation of Trichoderma virens and Burkholderia cepacia for antagonistic activity against root-knot nematode, Meloidogyne incognita. Nematology 2000, 2, 871-879.

105. Colagiero, M.; Rosso, L.C.; Ciancio, A. Diversity and biocontrol potential of bacterial consortia associated to root-knot nematodes. Biol. Control. 2018, 120, 11-16. [CrossRef]

106. Son, S.H.; Khan, Z.; Kim, S.G.; Kim, Y.H. Plant growth-promoting rhizobacteria, Paenibacillus polymyxa and Paenibacillus lentimorbus suppress disease complex caused by root-knot nematode and Fusarium wilt fungus. J. Appl. Microbiol. 2009, 107, 524-532. [CrossRef] [PubMed]

107. Oliveira, D.F.; Campos, V.P.; Amaral, D.R.; Nunes, A.S.; Pantaleão, J.A.; Costa, D.A. Selection of rhizobacteria able to produce metabolites active against Meloidogyne exigua. Eur. J. Plant Pathol. 2007, 119, 477-479. [CrossRef]

108. Kermarrec, A.; Jacqua, G.; Anais, J. Effect of Fusarium solani and Pseudomonas solanacearum on the infestation of aubergine with the plant-parasitic nematode Rotylenchulus reniformis. Nematologica 1994, 40, 152-154.

109. Siddiqui, Z.A.; Singh, L.P. Effects of fly ash, Pseudomonas striata and Rhizobium on the reproduction of nematode Meloidogyne incognita and on the growth and transpiration of pea. J. Environ. Biol. 2005, 26, 117-122.

110. Seenivasan, N.; Parameswaran, S.; Sridar, P.; Gopalakrishnan, C.; Gnanamurthy, P. Application of Bioagents and Neem Cake as Soil Application for the Management of Root-knot Nematode in Turmeric. National Congress on Centenary of Nematology in India Appraisal and Future Plans; Indian Agricultural Research Institute: New Delhi, India, 2001; p. 164.

111. Insunza, V.; Alström, S.; Eriksson, K.B. Root bacteria from nematicidal plants and their biocontrol potential against trichodorid nematodes in potato. Plant Soil. 2002, 241, 271-278. [CrossRef]

112. Rashad, F.; Fathy, H.; Samir, A.; Elghonaimy, A. Isolation and characterization of multifunctional Streptomyces species with antimicrobial, nematicidal and phytohormone activities from marine environments in Egypt. Microbiol. Res. 2015, 175, 34-47. [CrossRef] [PubMed]

113. Hussey, R.S.; Grundler, F.M. Nematode parasitism of plants. In Physiology and Biochemistry of Free-Living and Plant Parasitic Nematodes; Perry, R.N., Wright, J., Eds.; 11 CAB International Press: Oxford, UK, 1988; pp. 213-243.

114. Singh, S.; Singh, B.; Singh, A.P. Nematodes: A threat to sustainability of agriculture. Procedia Environ. Sci. 2015, 29, 215-216. [CrossRef]

115. Sikkens, R.B.; Weaver, D.B.; Lawrence, K.S.; Moore, S.R.; van Santen, E. LONREN upland cotton germ-plasm response to Rotylenchulus reniformis inoculum level. Nematropica 2011, 6, 68-74.

116. Roshi, R.A.; King, R.L.; Lawrence, G.W. Classification of Rothylenhulus reniformis numbers in cotton using remotely sensed hyperspectral data on self-organizing maps. J. Nematol. 2010, 42, 179-193.

117. Weaver, D.B. Cotton nematodes. In Cotton, 2nd ed.; Fang, D.D., Rercy, R.G., Eds.; ASA, CSSA, and SSSA: Madison, WI, USA, 2015; pp. 547-570.

118. Elhady, A.; Giné, A.; Topalovic, O.; Jacquiod, S.; Sørensen, S.J.; Sorribas, F.J.; Heuer, H.; Castagnone-Sereno, P. Microbiomes associated with infective stages of root-knot and lesion nematodes in soil. PLoS ONE 2017, 12, e0177145. [CrossRef]

119. Bernard, G.C.; Egnin, M.; Bonsi, C. The impact of plant-parasitic nematodes on agriculture and methods of control. In Nematology—Concepts, Diagnosis and Control; Shah, M.M., Mohammod, M., Eds.; IntechOpen: London, UK, 2017; pp. 121-151. 
120. Pimentel, D. Environmental and economic costs of the application of pesticides primarily in the United States. Environ. Dev. Sustain. 2005, 7, 229-252. [CrossRef]

121. Mitiku, M. Plant-parasitic nematodes and their management: A review. Agric. Res. Technol. Open Access J. 2016, 16, 555980. [CrossRef]

122. Shepherd, R.L.; Huck, M.G. Progression of root-knot nematode symptoms and infection on resistant and susceptible cottons. J. Nematol. 1989, 2, 235-241.

123. Rhoads, M.L. Cholinesterase in the parasitic nematode, Stephanurus denatus. J. Biochem. 1981, 17, $9316-9323$.

124. Chitwood, B.G. "Root-knot Nematodes"-Part I. A revision of the genus Meloidogyne goeldi, 1887. Proc. Helminthol. Soc. Wah. 1949, 16, 90-104.

125. Johnson, A.; Dowler, C.; Handoo, Z. Population dynamics of Meloidogyne incognita, M. arenaria and other nematodes and crop yields in rotations of cotton, peanut, and wheat under minimum tillage. J. Nematol. 2000, 32, 52-61. [PubMed]

126. Vyska, M.; Cunniffe, N.; Gilligan, C. Trade-off between disease resistance and crop yield: A landscape-scale mathematical modeling perspective. J. R. Soc. Interface 2016, 13, 20160451. [CrossRef]

127. Trudgill, D.L. Resistance to and tolerance of plant parasitic nematodes in plants. Ann. Rev. Phytopathol. 1991, 29, 167-192. [CrossRef]

128. Siddiqui, Z.A.; Mahmood, I. Role of bacteria in the management of plant parasitic nematodes: A Review. Bioresour. Technol. 1999, 69, 167-179. [CrossRef]

129. Wani, A.H. Plant growth-promoting rhizobacteria as biocontrol agents of phytonematodes. In Biocontrol Agents of Phytonematodes; Askary, T.H., Martinelli, P.R.P., Eds.; CAB International: Wallingford, UK, 2015; pp. 339-362.

130. Lugtenberg, B.; Kamilova, F. Plant-growth-promoting rhizobacteria. Annu. Rev. Microbiol. 2009, 63, 541-556. [CrossRef] [PubMed]

131. Van Loon, L.C.; Bakker, P.A.H.M.; Pieterse, C.M.J. Systemic resistance induced by rhizosphere bacteria. Annu. Rev. Phytopathol. 1998, 36, 453-483. [CrossRef] [PubMed]

132. Bishop, A. Pasteuria penetrans and its parasitic interaction with plant parasitic nematodes. In Endospore-Forming Soil Bacteria; Logan, N.A., de Vos, P., Eds.; Springer: Berlin/Heidelberg, Germany, 2011; pp. 181-201.

133. Starr, M.P.; Sayre, R.M. Pasteuria thornei sp. nov. and Pasteuria penetrans sensu stricto emend., mycelial and endospore-forming bacteria parasitic, respectively, on plant-parasitic nematodes of the genera Pratylenchus and Meloidogyne. Ann. Inst. Pasteur. Microbiol. 1988, 139, 11-31. [CrossRef]

134. Migula, W. Über ein neues System der Bakterien. Arab Bacteriol. Inst. Karlsr. 1984, 1, $235-328$.

135. Migula, W. System der Bakteriem; Gustav Fischer: Jena, Germany, 1900; Volume 2.

136. Maksimov, I.V.; Abizgil'dina, R.R.; Pusenkova, L.I. Plant growth promoting rhizobacteria as alternative to chemical crop protectors from pathogens (Review). Appl. Biochem. Microbiol. 2011, 47, 333-345. [CrossRef]

137. Frankland, S.G.; Frankland, R.F. Studies on some new microorganisms obtained from air. Royal Soc. Lon-don Phil. Trans. Ser. B Biol. Sci. 1887, 178, 257-287.

138. Bredemann, G.; Werner, W. Botanische beschreibung haufinger am buttersaureabbau beteiligter sporenbildender bakterienspezies. Zentralbl. Bakteriol. Parasitenkd. Infektionskr. Hyg. Abt. II 1933, 87, 446-475.

139. Chester, F.D. A Manual of Determinative Bacteriology; The Macmillan Co.: New York, NY, USA, 1901; pp. 1-401.

140. De Bary, A. Vergleichende Morphologie und Biologie der Pilze, Mycetozoen und Bacterien; Wilhelm Engelmann: Leipzig, Germany, 1884.

141. Cohn, F. Untersuchungen uber Bakterien. Beitr. Biol. Pflanz. 1872, 1, 127-224.

142. Collins, M.D.; Smida, J.; Dorsch, M.; Stackebrandt, E. Tsukamurella gen. nov. harboring Corynebacterium paurometabolum and Rhodococcus aurantiacus. Int. J. Syst. Bacteriol. 1988, 38, 385-391. [CrossRef]

143. Ramamoorthy, V.; Viswanathan, R.; Raguchander, T.; Prakasam, V.; Samiyappan, R. Induction of systemic resistance by plant growth promoting rhizobacteria in crop plants against pests and diseases. Crop Prot. 2001, 20,1-11. [CrossRef]

144. Babalola, O.O. Beneficial bacteria of agricultural importance. Biotechnol. Lett. 2010, 32, 1559-1570. [CrossRef]

145. Ichinohe, M. On the soybean nematode, Heterodera glycines n. sp., from Japan (trans.). Oyo-Dobutsugaku-Zasshi 1952, 17, 1-4.

146. Koshy, P.K. A new species of Heterodera from India. Indian Phytopathol. 1967, 20, $272-274$.

147. Stone, A.R. Heterodera pallida n. sp. (Nematoda: Heteroderidae), a second species of potato cyst nematode. Nematologica 1973, 18, 591-606. [CrossRef] 
148. Priest, F.G.; Goodfellow, M.; Shute, L.A.; Berkeley, R.C.W. Bacillus amyloliquefaciens sp. nov., nom. rev. Int. J. Syst. Bacteriol. 1987, 37, 69-71. [CrossRef]

149. Golden, A.M.; Birchfield, W. Rice root-knot nematode (Meloidogyne graminicola) as a new pest of rice. Plant Dis. Rep. $1968,52,423$.

150. Krall, E.L.; Krall, H.A. Revision of the plant nematodes of the family Heteroderidae on the basis of the trophic specialization of these parasites and their co-evolution with their host plants. In Fitogel'Mintologi-Cheskie Issledovaniya. Moscow; Nauka: Moscow, USSR, 1978; pp. 39-56.

151. Schmidt, A. Über den Rüben-Nematoden (Heterodera schachtii A.S.). Z. Ver. Die Rüben-Zucker-Ind. Zollverein 1871, 21, 1-19.

152. Filipjev, I.N.; Schuurmans Stekhoven, J.H., Jr. A Manual of Agricultural Helminthology; Brill: Leiden, The Netherland, 1941; p. 878.

153. Nahar, K.; Kyndt, T.; De Vleesschauwer, D.; Höfte, M.; Gheysen, G. The jasmonate pathway is a key player in systemically induced defense against root knot nematodes in rice. Plant Physiol. 2011, 157, 305-331. [CrossRef] [PubMed]

154. Fujimoto, T.; Tomitaka, Y.; Abe, H.; Tsuda, S.; Futai, K.; Mizukubo, T. Expression profile of jasmonic acid-induced genes and the induced resistance against the root-knot nematode (Meloidogyne incognita) in tomato plants (Solanum lycopersicum ) after foliar treatment with methyl jasmonate. J. Plant Physiol. 2011, 168, 1084-1097. [CrossRef] [PubMed]

155. Hubbard, K.E.; Nishimura, N.; Hitomi, K.; Getzoff, E.D.; Schroeder, J.I. Early abscisic acid signal transduction mechanisms: Newly discovered components and newly emerging questions. Genes Dev. 2010, 24, 1695-1708. [CrossRef]

156. Lee, S.C.; Luan, S. ABA signal transduction at the crossroad of biotic and abiotic stress responses. Plant Cell Environ. 2012, 35, 53-60. [CrossRef]

157. Daszkowska-Golec, A.; Szarejko, I. The molecular basis of ABA-mediated plant response to drought. In Abiotic Stress-Plant Responses and Applications in Agriculture; Vahdati, K., Leslie, C., Eds.; IntechOpen: Rijeka, Croatia, 2013; Available online: https://www.intechopen.com/books/abiotic-stress-plant-responses-andapplications-in-agriculture/the-molecular-basis-of-aba-mediated-plant-response-to-drought (accessed on 3 September 2020).

158. Der Ent, S.V.; Hulten, M.V.; Pozo, M.J.; Czechowski, T.; Udvardi, M.K.; Pieterse, C.M.J.; Ton, J. Priming of plant innate immunity by rhizobacteria and $\beta$-aminobutyric acid: Differences and similarities in regulation. New Phytol. 2009, 183, 419-431. [CrossRef]

159. de Toni, J.B.; Trevisan, V. Schizomycetaceae Naeg. In Sylloge Fungorum Omnium Hujusque Cognitorum; Saccardo, P.A., Ed.; Sumptibus Auctoris: Berlin, Germany, 1889; Volume 8, pp. 923-1087.

160. Pieterse, C.M.; van Wees, S.C.; van Pelt, J.A.; Knoester, M.; Laan, R.; Gerrits, H.; Weisbeek, P.J.; van Loon, L.C. A novel signaling pathway controlling induced systemic resistance in Arabidopsis. Plant Cell 1998, 10, 1571-1580. [CrossRef]

161. Ramírez, V.; Van der Ent, S.; García-Andrade, J.; Coego, A.; Pieterse, C.M.; Vera, P. OCP3 is an important modulator of NPR1-mediated jasmonic acid-dependent induced defenses in Arabidopsis. BMC Plant Biol. 2010, 10, 199. [CrossRef]

162. Cominelli, E.; Galbiati, M.; Vavasseur, A.; Conti, L.; Sala, T.; Vuylsteke, M.; Leonhardt, N.; Dellaporta, S.L.; Tonelli, C. A guard-cell-specific MYB transcription factor regulates stomatal movements and plant drought tolerance. Curr. Biol. 2005, 15, 1196-1200.

163. Lim, C.W.; Baek, W.; Jung, J.; Kim, J.-H.; Lee, S.C. Function of ABA in stomatal defense against biotic and drought stresses. Int. J. Mol. Sci. 2015, 16, 15251-15270. [CrossRef]

164. Huang, H.; Gao, H.; Liu, B.; Qi, T.; Tong, J.; Xiao, L.; Xie, D.; Song, S. Arabidopsis MYB24 regulates jasmonate-mediated stamen development. Front. Plant Sci. 2017, 8, 1525. [CrossRef]

165. Feys, B.; Benedetti, C.E.; Penfold, C.N.; Turner, J.G. Arabidopsis mutants selected for resistance to the phytotoxin coronatine are male sterile, insensitive to methyl jasmonate, and resistant to a bacterial pathogen. Plant Cell 1994, 6, 751-759. [CrossRef]

166. Mosblech, A.; Thurow, C.; Gatz, C.; Feussner, I.; Heilmann, I. Jasmonic acid perception by COI1 involves inositol polyphosphates in Arabidopsis thaliana. Plant J. 2011, 65, 949-957. [CrossRef]

167. Liu, Y.; Lai, Q.; Shao, Z. Genome analysis-based reclassification of Bacillus weihenstephanensis as a later heterotypic synonym of Bacillus mycoides. Int. J. Syst. Evol. Microbiol. 2018, 68, 106-112. [CrossRef] 
168. Meyer, A.; Gottheil, O. Botanische beschreibung einiger bodenbakterien. Zentralbl. Bakteriol. Parasitenkd. Infektionskr. Hyg. Abt. II 1901, 7, 680-691.

169. Chaverri, P.; Samuels, G.J. Hypocrea lixii, the teleomorph of Trichoderma harzianum. Mycol. Prog. 2002, 1, 283-286. [CrossRef]

170. Martinez- Medina, A.; Appels, F.V.W.; van Wees, S.C.M. Impact of salicylic acid- and jasmonic acid-defences on root colonization of Trichoderma harzianum T-78. Plant Signal. Behav. 2017, 12, 1345414. [CrossRef]

171. Glazebrook, J. Contrasting mechanisms of defense against biotrophic and necrotrophic pathogens. Ann. Rev. Phytopathol. 2005, 43, 205-227. [CrossRef]

172. Gimenez-Ibanez, S.; Solano, R. Nuclear jasmonate and salicylate signaling and crosstalk in defense against pathogens. Front. Plant Sci. 2013, 4, 72. [CrossRef]

173. Pena-Cortés, H.; Albrecht, T.; Prat, S.; Weiler, E.W.; Willmitzer, L. Aspirin prevents wound-induced gene expression in tomato leaves by blocking jasmonic acid biosynthesis. Planta 1993, 191, 123-128. [CrossRef]

174. Uppalapati, S.R.; Ishiga, Y.; Wangdi, T.; Kunkel, B.N.; Anand, A.; Mysore, K.S.; Bender, C.L. The phytotoxin coronatine contributes to pathogen fitness and is required for suppression of salicylic acid accumulation in tomato inoculated with Pseudomonas syringae pv. tomato DC3000. Mol. Plant Microbe Interact. 2007, 20, 955-965. [CrossRef] [PubMed]

175. Tamaoki, D.; Seo, S.; Yamada, S.; Kano, A.; Miyamoto, A.; Shishido, H.; Miyoshi, S.; Taniguchi, S.; Akimitsu, K.; Gomi, K. Jasmonic acid and salicylic acid activate a common defense system in rice. Plant Signal. Behav. 2013, 8, 24260. [CrossRef] [PubMed]

176. Van der Does, D.; Leon-Reyes, A.; Koornneef, A.; Van Verk, M.C.; Rodenburg, N.; Pauwels, L.; Goossens, A.; Körbes, A.P.; Memelink, J.; Ritsema, T.; et al. Salicylic acid suppresses jasmonic acid signaling downstream of SCFCOI1-JAZ by targeting GCC promoter motifs via transcription factor ORA59. Plant Cell. 2013, 25, 744-761. [CrossRef]

177. Whetzel, H.H. A synopsis of the genera and species of the Sclerotiniaceae, a family of stromatic inoperculate discomycetes. Mycologia 1945, 37, 648-714. [CrossRef]

178. Mitter, N.; Kazan, K.; Way, H.M.; Broekaert, W.F.; Manners, J.M. Systemic induction of an Arabidopsis plant defensin gene promoter by tobacco mosaic virus and jasmonic acid in transgenic tobacco. Plant Sci. 1998, 136, 169-180. [CrossRef]

179. Clarke, J.D.; Volko, S.M.; Ledford, H.; Ausubel, F.M.; Dong, X. Roles of salicylic acid, jasmonic acid, and ethylene in cpr-induced resistance in Arabidopsis. Plant Cell 2000, 12, 2175-2190. [CrossRef]

180. Mur, L.A.J.; Kenton, P.; Atzorn, R.; Miersch, O.; Wasternack, C. The outcomes of concentration-specific interactions between salicylate and jasmonate signaling include synergy, antagonism, and oxidative stress leading to cell death. Plant Physiol. 2006, 140, 249-262. [CrossRef]

181. Shafi, J.; Tian, H.; Ji, M. Bacillus species as versatile weapons for plant pathogens: A review. Biotechnol. Biotechnol. Equip. 2017, 31, 446-459. [CrossRef]

182. Kloepper, J.W.; Lifshitz, R.; Zablotowicz, R. Free-living bacterial inocula for enhancing crop productivity. Trends Biotechnol. 1989, 7, 39-44. [CrossRef]

183. Vacheron, J.; Desbrosses, G.; Bouffaud, M.-L.; Touraine, B.; Moënne-Loccoz, Y.; Muller, D.; Legendre, L.; Wisniewski-Dyé, F.; Prigent-Combaret, C. Plant growth-promoting rhizobacteria and root system functioning. Front. Plant Sci. 2013, 4, 356. [CrossRef]

184. Kloepper, J.W.; Ryu, C.-M.; Zhang, S. Induced systemic resistance and promotion of plant growth by Bacillus spp. Phytopathology 2004, 94, 1259-1266. [CrossRef] [PubMed]

(C) 2020 by the authors. Licensee MDPI, Basel, Switzerland. This article is an open access article distributed under the terms and conditions of the Creative Commons Attribution (CC BY) license (http://creativecommons.org/licenses/by/4.0/). 